\title{
PENINGKATAN PRODUKSI ULAT JERMAN MELALUI KOMBINASI PEMANFAATAN LIMBAH SAYURAN PASAR PADA FORMULASI MEDIA PAKAN YANG BERBEDA
}

\author{
Erik Priyo Santoso, Akhadiyah Afrila dan Eka Fitasari \\ Fakultas Pertanian Universitas Tribhuwana Tunggadewi
}

\begin{abstract}
Waste vegetable of traditional market provided very abundant and rarely used. German mealworm known as giant meal worms are the larvae of insects named Zhopobas morio parent has a size larger than the hongkong mealworm. The purpose of this study was to determine the application of vegetable waste in feed media of German mealworm which has a different nutrient content. This experiment using a completely randomized design (CRD) factorial design with treatment G1P1 (GE $4000 \mathrm{kcal} / \mathrm{kg}$, PK 10\%), G1P2 (GE $4000 \mathrm{kcal} / \mathrm{kg}$, PK 12\%), G1P3 (GE $4000 \mathrm{kcal} / \mathrm{kg}$, PK 14\% ), G2P1 (GE $4500 \mathrm{kcal} /$ $\mathrm{kg}$, PK 10\%), G2P2 (GE $4500 \mathrm{kcal} / \mathrm{kg}$, PK 12\%), G2P3 (GE $4500 \mathrm{kcal} / \mathrm{kg}$, PK 14\%), G3P1 (GE $5000 \mathrm{kcal} / \mathrm{kg}$ PK $10 \%$ ) G3P2 (GE $5000 \mathrm{kcal} / \mathrm{kg}$ PK 12\%), G3P3 (GE $5000 \mathrm{kcal} / \mathrm{kg}$ PK 14\%), each treatments replicated 3 times. The results of the research showed that the application of vegetable waste in german worm feed media is able to increase the use of feed concentrates containing gross energy and crude protein low. Vegetable waste treatment in feed media which containing gross energy of 4000 $\mathrm{kcal} / \mathrm{kg}$ and $14 \%$ crude protein showing the highest value on dry matter feed intake, weight of the harvest, and worm weight gain.
\end{abstract}

Keywords : jerman worm, Vegetable waste market, feed, energy, protein

\section{Pendahuluan}

Ulat jerman yang dikenal dengan nama King Mealworm (Zophobas morio) merupakan bahan pakan popular yang banyak digunakan para penghobi untuk diberikan kepada reptil, burung kicauan, dan unggas lainnya. Penggemar burung dan reptil di mancanegara sering menyebutnya superworm. Ukuran tubuhnya bisa 7 kali lipat lebih besar daripada ulat hongkong. Ulat jerman juga dianggap lebih aman ketimbang ulat jerman yang banyak digunakan penggemar burung di Indonesia.

Belakangan ini budidaya ulat jerman mulai marak di Indonesia, meski jumlahnya masih kalau dibandingkan dengan jumlah pembudidaya ulat jerman. Awalnya, bibit ulat jerman didatangkan dari Amerika Tengah dan Amerika Selatan. Sekarang tak perlu impor lagi, karena sudah banyak yang mengembangbiakkannya di Indonesia untuk pakan burung dan reptil. Selain itu, kandungan protein dan zat gizi lainnya pada ulat jerman juga lebih tinggi daripada ulat jerman. Bahkan, ulat jerman juga memiliki sistem kekebalan tubuh yang lebih tinggi, sehingga ketika termakan burung bisa membantunya dalam menangkal berbagai agen penyakit seperti virus, bakteri, jamur, maupun parasit.

Semua ini makin menegaskan kalau ulat jerman lebih aman dan bermanfaat bagi burung kicauan daripada ulat jerman. Berikut ini beberapa kandungan gizi pada ulat jerman : Protein : 19,06 \%, 
Lemak : 14,19 \%, Kalsium : 173 ppm, Serat kasar: 2,60 \% (Munandi, 2015)

Selain nilai gizinya lebih tinggi, kandungan khitin (exoskeleton) pada ulat jerman jauh lebih sedikit daripada ulat jerman. Dengan demikian, pakan ini lebih mudah dicerna dan aman bagi saluran pencernaan burung, meski burung mengkonsumsinya dalam jumlah banyak.

Pakan yang digunakan untuk ulat jerman, umumnya masih menggunakan polar dan jenis konsentrat lain yang murah. Bahan konsentrat juga bida diperoleh dari limbah pertanian, seperti gamblong, bekatul, dan bahan lainnya. Selain itu, peternak juga menambahkan sayuran dan buah-buahan. Semua pakan yang digunakan untuk ulat jerman masih mengacu seperti pakan yang digunakan untuk ulat jerman.. Padahal, postur tubuh yang berbeda tentunya juga memerlukan kebutuhan nutrisi yang berbeda pula. Penentuan nutrisi bagi ternak adalah dengan membuat formulasi tertentu pada media ulat jerman yang merupakan bahan yang kaya akan energy dan protein. Sementara penggunaan limbah sayuran ataupun hijauan lainnya adalah sebagai pelengkap nutrisi bagi media pakan karena dapat mengenyangkan, sebagai sumber air, dan bila digunakans ecara tepat juga memberikan kontribusi terhadap ketubuhan nutrisi ulat jerman.

Malang merupakan salah satu kota pendidikan di Indonesia yang memiliki populasi penduduk yang cukup padat. Populasi in selain dipenuhi oleh penduduk asli, juga dipenuhi oleh pendatang yang rata-rata berasal dari mahasiswa yang bersekolah di Malang. Jumlah populasi yang banyak menyebabkan menjamurnya berbagai bisnis rumah makan dan pasar-pasar yang menjual kebutuhan pokok dan sayuran. Sehingga, jumlah sampah setiap harinya sangat besar sekali. Hasil penelitian Haffandi (2013), jumlah gerobak yang masuk ke TPS dari jam 06.00 - 08.00 (2 jam) berjumlah 15 gerobak. Jumlah TPS yang ada di kota malang, yaitu 73 TPS. Setelah jumlah sampah dikonversi (berat sampah (gram) $\mathrm{x} 8 \mathrm{x}$ jumlah gerobak $\mathrm{x}$ jumlah TPS seluruh kota Malang) maka dapat diperkirakan berat sampah diseluruh TPS kota Malang yaitu sebesar 33.769 .800 gram ( $\sim 33,8$ ton) dengan rata-rata berat sampah organik organik (wortel, sayuran hijau) sebesar 19.710.000 gr.

Salah satu solusi pemanfaatan sampah organik adalah dapat dimanfaatkan sebagai pakan ulat jerman, sebagai pakan alternatif yang murah dan jumlahnya cukup melimpah dan kontinyu. Perbedaan jenis pakan yang diberikan untuk ulat jerman menyebabkan perbedaan pada hasil panen dan bobot badan panen. Oleh karena itu, perlu diteliti penggunaan dari limbah sayuran pasar dan buah-buahan pada media pakan yang berbeda terhadap produksi ulat jerman.

Hasil penelitian Hartiningsih dan Fitasari (2014) dilaporkan bahwa penggunaan limbah sayuran pasar mampu meningkatkan bobot panen ulat jerman pada fase pemeliharaan umur 15 - 25 hari. Namun, aplikasinya setelah umur 25 hari hingga panen belum diketahui. Oleh karena itu pada penelitian ini perlu dilakukan untuk mengetahui bagaimana pemanfaatan limbah sayuran pasar yang diaplikasikan pada formulasi pakan dengan kandungan nutrisi yang berbeda mulai dari awal pemeliharaan hingga panen mampu meningkatkan produksi dan bobot panen ulat jerman.

\section{Metode Penelitian}

Tempat dan Waktu

Penelitian dilaksanakan pada bulan Mei 2016 sampai Juli 2016 di Peternakan 
Rakyat milik Bapak Banu di Semanding, Dau, Kabupaten Malang. Analisis proksimat dilakukan di Laboratorium Nutrisi dan Makanan Ternak Universitas Brawijaya.

\section{Materi}

Ulat jerman yang digunakan untuk penelitian adalah berumur 15 hari hingga umur panen yaitu 50 hari diperoleh dari peternak ulat jerman milik Bapak Riyanto Joko, Turen, Kabupaten Malang.

\section{Kandang dan Fasilitas Kandang}

Kandang yang digunakan dalam penelitian ini adalah berupa nampannampan yang disusun dalam sebuah rak dan ditempatkan pada ruangan bersuhu $25-30{ }^{\circ} \mathrm{C}$ dan tidak boleh terkena sinar matahari langsung. 1 buah nampan berisi 200 ekor ulat jerman. Peralatan yang digunakan meliputi timbangan (untuk menimbang maksimal $100 \mathrm{gr}$ ), timbangan digital kapasitas maximal 5, seperangkat alat untuk pemeliharaan ulat, jangka sorong digital, oven suhu $105{ }^{\circ} \mathrm{C}$ untuk mengukur kadar air pakan.

Metode Pelaksanaan

Tabel 1. Sumber-sumber bahan pakan untuk formulasi pakan ulat jerman dan kandungannya

\begin{tabular}{clrrrrrr}
\hline No & \multicolumn{1}{c}{ Bahan Pakan } & $\begin{array}{c}\text { GE } \\
(\mathrm{kkal} / \mathrm{kg})\end{array}$ & $\begin{array}{c}\text { PK } \\
(\%)\end{array}$ & $\begin{array}{c}\text { LK } \\
(\%)\end{array}$ & $\begin{array}{c}\text { SK } \\
(\%)\end{array}$ & $\begin{array}{c}\text { Ca } \\
(\%)\end{array}$ & $\begin{array}{c}\text { P } \\
(\%)\end{array}$ \\
\hline 1 & POLAR & 4304.11 & 16.88 & 4.98 & 8.68 & 4.42 & 86.96 \\
2 & MPOK JAGUNG & 4682 & 8.62 & 3.97 & 2.23 & 1.63 & 84.62 \\
3 & GAMBLONG KERING & 4107.46 & 1.07 & 0.24 & 19.96 & 2.33 & 90.69 \\
4 & AMPAS TAHU KERING & 4010 & 22.64 & 6.12 & 22.65 & 2.62 & 0 \\
5 & MINYAK SAWIT & 9000 & 0 & 0 & 0 & 0 & 0 \\
\hline
\end{tabular}

\section{Variabel Penelitian}

- Konsumsi pakan : Konsumsi pakan $(\mathrm{g} /$ ekor $)=$ pemberian awal - pakan sisa, penghitungan dilakukan berdasarkan Bahan kering
Penelitian lapang dilakukan dengan mengaplikasikan limbah sayuran yang ketersediaannya melimpah yang diambil dari pasar Mertojoyo, Malang, dan diaplikasikan bersama-sama dengan formulasi media pakan yang berbeda yang disusun berdasarkan kombinasi kadar protein dan energi yang berbeda. Pemberian pakan berupa hijauan dan konsentrat diberikan secara adlibitum. Metode penelitian menggunakan Rancangan Acak Lengkap pola faktorial engan faktor 1 yaitu GE = 4000, 4500, dan $5000 \mathrm{kkal} / \mathrm{kg}$, dan faktor 2 adalah Protein Kasar $(\mathrm{PK})=10 \%, 12 \%$, dan 14\% sehingga terdapat 9 perlakuan dan 3 ulangan. Adapun perlakuan yang digunakan adalah sebagai berikut: G1P1 $=\mathrm{GE} 4000 \mathrm{kkal} / \mathrm{kg}$, PK 10\% ; G1P2 = GE $4000 \mathrm{kkal} / \mathrm{kg}$, PK 12\% ; G1P3 = GE $4000 \mathrm{kkal} / \mathrm{kg}$, PK 14\%; G2P1 = GE $4500 \mathrm{kkal} / \mathrm{kg}$ PK 10\%; G2P2 = GE $4500 \mathrm{kkal} / \mathrm{kg} \mathrm{PK} 12 \% ; \mathrm{G} 2 \mathrm{P} 3=\mathrm{GE}$ $4500 \mathrm{kkal} / \mathrm{kg}$ PK 14\%; G3P1 = GE $5000 \mathrm{kkal} / \mathrm{kg}$ PK 10\%; G3P2 = GE $5000 \mathrm{kkal} / \mathrm{kg}$ PK 12\%; G3P3 = GE $5000 \mathrm{kkal} / \mathrm{kg} \quad \mathrm{PK} \quad 14 \%$. Untuk pembuatan formulasi pakan, jenis-jenis bahan pakan yang digunakan ditunjukkan pada Tabel 1. 
secara acak (untuk perlakuan dan ulangan yang sama) sebanyak $5-10 \%$

- Konversi pakan

Konversi pakan = jumlah konsumsi pakan

Analisa Data

Data yang diperoleh akan diuji secara statistik dengan menggunakan Rancangan Acak Lengkap pola faktorial. Apabila ada perbedaan yang nyata maka dilanjutkan dengan Uji Beda Nyata Terkecil (BNT) (Yitnosumarto, 1993).

\section{Hasil dan Pembahasan}

Penggunaan limbah sayur sebagai pakan ternak ulat jerman masih belum banyak digunakan, padahal potensi dan jumlahnya sangat melimpah. Selama ini bagi ulat hongkong maupun pad aulat jerman, fungsi limbah sayur masih digantikan oleh buah pepaya muda. Bagi ulat jerman pepaya muda serutan berfungsi sebagai sumber air dan pakan tambahan. Hasil penelitian Hartiningsih dan Fitasari (2014) dilaporkan bahwa limbah sayur mampu menggantikan penggunaan pepaya sebagai sumber air dan pakan tambahan bagi ulat hongkong. Hasil penelitian menunjukkan bahwa limbah sayuran memberikan hasil sama bagus dibandingkan limbah kulit buahbuahan. Dari segi ekonomi, limbah sayuran sangat menguntungkan karena tersedia dalam jumlah melimpah di pasar dan tanpa harus membeli. Sementara, atau pepaya muda pemenuhannya masih harus mengeluarkan biaya. Berdasarkan hasil penelitian Hartiningsih dan Fitasari (2014), limbah sayur mengandung nutrisi yang cukup tinggi yaitu BK 86,63\%, Abu $14,05 \%$, PK $22,78 \%$, SK $15,90 \%$, LK $1,82 \%$ dan gross energy $4624,94 \mathrm{kkal} / \mathrm{kg}$.

Dalam penelitian ini adalah limbah sayur pasar yang diperoleh secara acak sesuai dengan kesediaan tiap hari seperti campuran dari kubis, bonggol sawi, pokchai, wortel, kulit kentang, sawi putih, dan manisa. Perhitungan konsumsi pakan didasarkan pada konsumsi bahan kering yang dihitung untk setiap jenis pakan yang dikonsumsi ulat.

Konsentrat merupakan pakan sumber protein dan energi yang digunakan untuk meningkatkan pertumbahan dan bobot badan ulat jerman yang diperoleh dari gamblong (limbah ketela pohon), mpok jagong, polar, ampas tahu, dan minyak. Pakan ini digunakan bersama-sama dengan limbah sayuran pasar untuk meningkatkan pertambahan bobot badan secara cepat dan diberikan sejak umur 15 hingga 50 hari. Adapun formulasi pakan dapat dilihat pada tabel 2 sampai dengan table 10 di bawah ini

Tabel 2. Kombinasi GE 4000 kkal dan protein kasar 10\%

\begin{tabular}{lrrrrrrr}
\hline \multicolumn{1}{c}{ Bahan Pakan } & \multicolumn{1}{c}{ \% } & EM & \multicolumn{1}{c}{ PK } & LK & \multicolumn{1}{c}{ SK } & Ca & \multicolumn{1}{c}{ P } \\
\hline POLAR & 10 & 430.41 & 1.688 & 0.498 & 0.868 & 0.442 & 8.696 \\
MPOK JAGUNG & 0 & 0 & 0 & 0 & 0 & 0 & 0 \\
GAMBLONG KERING & 55 & 2259.1 & 0.5885 & 0.132 & 10.978 & 1.2815 & 49.88 \\
AMPAS TAHU KERING & 35 & 1403.5 & 7.924 & 2.142 & 7.9275 & 0.917 & 0 \\
& 100.00 & 4093 & 10.201 & 2.772 & 19.774 & 2.6405 & 58.576 \\
\hline
\end{tabular}

Tabel 3. Kombinasi GE $4000 \mathrm{kkal}$ dan protein kasar 12\%

\begin{tabular}{lrrrrrrr}
\hline \multicolumn{1}{c}{ Bahan Pakan } & \multicolumn{1}{c}{ \% } & \multicolumn{1}{c}{ GE } & \multicolumn{1}{c}{ PK } & \multicolumn{1}{c}{ LK } & \multicolumn{1}{c}{ SK } & Ca & \multicolumn{1}{c}{ P } \\
\hline POLAR & 13 & 559.53 & 2.1944 & 0.6474 & 1.1284 & 0.5746 & 11.305 \\
MPOK JAGUNG & 0 & 0 & 0 & 0 & 0 & 0 & 0 \\
GAMBLONG KERING & 44 & 1807.3 & 0.4708 & 0.1056 & 8.7824 & 1.0252 & 39.904 \\
AMPAS TAHU KERING & 43 & 1724.3 & 9.7352 & 2.6316 & 9.7395 & 1.1266 & 0 \\
& 100.00 & 4091.1 & 12.4 & 3.3846 & 19.65 & 2.7264 & 51.208 \\
\hline
\end{tabular}


E. P. Santoso, A. Afrila dan E. Fitasari / Buana Sains Vol 17 No 1: 33 - 42

Tabel 4. Kombinasi GE 4000 kkal dan protein kasar 14\%

\begin{tabular}{lrrrrrrr}
\hline \multicolumn{1}{c}{ Bahan Pakan } & \multicolumn{1}{c}{ \% } & GE & PK & LK & SK & Ca & \multicolumn{1}{c}{ P } \\
\hline POLAR & 20 & 860.82 & 3.376 & 0.996 & 1.736 & 0.884 & 17.392 \\
MPOK JAGUNG & 0 & 0 & 0 & 0 & 0 & 0 & 0 \\
GAMBLONG KERING & 31 & 1273.3 & 0.3317 & 0.0744 & 6.1876 & 0.7223 & 28.114 \\
AMPAS TAHU KERING & 49 & 1964.9 & 11.094 & 2.9988 & 11.099 & 1.2838 & 0 \\
& 100.00 & 4099 & 14.801 & 4.0692 & 19.022 & 2.8901 & 45.506 \\
\hline
\end{tabular}

Tabel 5. Kombinasi GE $4500 \mathrm{kkal}$ dan protein kasar 10\%

\begin{tabular}{lrrrrrrr}
\hline \multicolumn{1}{c}{ Bahan Pakan } & \multicolumn{1}{c}{ \% } & \multicolumn{1}{c}{ GE } & PK & LK & \multicolumn{1}{c}{ SK } & Ca & \multicolumn{1}{c}{ P } \\
\hline POLAR & 30 & 1291.2 & 5.064 & 1.494 & 2.604 & 1.326 & 26.088 \\
MPOK JAGUNG & 50 & 2341 & 4.31 & 1.985 & 1.115 & 0.815 & 42.31 \\
GAMBLONG KERING & 16 & 657.19 & 0.1712 & 0.0384 & 3.1936 & 0.3728 & 14.51 \\
AMPAS TAHU KERING & 2.4 & 96.24 & 0.5434 & 0.1469 & 0.5436 & 0.0629 & 0 \\
MINYAK SAWIT & 1.6 & 144 & 0 & 0 & 0 & 0 & 0 \\
& 100.00 & 4529.7 & 10.089 & 3.6643 & 7.4562 & 2.5767 & 82.908 \\
\hline
\end{tabular}

Tabel 6. Kombinasi GE $4500 \mathrm{kkal}$ dan protein kasar 12\%

\begin{tabular}{lrrrrrrr}
\hline \multicolumn{1}{c}{ Bahan Pakan } & \multicolumn{1}{c}{ \% } & \multicolumn{1}{c}{ GE } & \multicolumn{1}{c}{ PK } & \multicolumn{1}{c}{ LK } & \multicolumn{1}{c}{ SK } & \multicolumn{1}{c}{ Ca } & \multicolumn{1}{c}{ P } \\
\hline POLAR & 31.9 & 1373 & 5.3847 & 1.5886 & 2.7689 & 1.41 & 27.74 \\
MPOK JAGUNG & 40 & 1872.8 & 3.448 & 1.588 & 0.892 & 0.652 & 33.848 \\
GAMBLONG KERING & 12.3 & 505.22 & 0.1316 & 0.0295 & 2.4551 & 0.2866 & 11.155 \\
AMPAS TAHU KERING & 13.5 & 541.35 & 3.0564 & 0.8262 & 3.0578 & 0.3537 & 0 \\
MINYAK SAWIT & 2.3 & 207 & 0 & 0 & 0 & 0 & 0 \\
& 100.00 & 4499.4 & 12.021 & 4.0323 & 9.1738 & 2.7023 & 72.743 \\
\hline
\end{tabular}

Tabel 7. Kombinasi GE $4500 \mathrm{kkal}$ dan protein kasar 14\%

\begin{tabular}{lrrrrrrr}
\hline \multicolumn{1}{c}{ Bahan Pakan } & \multicolumn{1}{c}{ \% } & GE & PK & LK & SK & Ca & P \\
\hline POLAR & 27 & 1162.1 & 4.5576 & 1.3446 & 2.3436 & 1.1934 & 23.479 \\
MPOK JAGUNG & 37 & 1732.3 & 3.1894 & 1.4689 & 0.8251 & 0.6031 & 31.309 \\
GAMBLONG KERING & 5 & 205.37 & 0.0535 & 0.012 & 0.998 & 0.1165 & 4.5345 \\
AMPAS TAHU KERING & 28 & 1122.8 & 6.3392 & 1.7136 & 6.342 & 0.7336 & 0 \\
MINYAK SAWIT & 3 & 270 & 0 & 0 & 0 & 0 & 0 \\
& 100.00 & 4492.6 & 14.14 & 4.5391 & 10.509 & 2.6466 & 59.323 \\
\hline
\end{tabular}

Tabel 8. Kombinasi GE $5000 \mathrm{kkal}$ dan protein kasar 10\%

\begin{tabular}{lrrrrrrr}
\hline \multicolumn{1}{c}{ Bahan Pakan } & \multicolumn{1}{c}{ \% } & \multicolumn{1}{c}{ GE } & PK & LK & \multicolumn{1}{c}{ SK } & Ca & \multicolumn{1}{c}{ P } \\
\hline POLAR & 11 & 473.45 & 1.8568 & 0.5478 & 0.9548 & 0.4862 & 9.5656 \\
MPOK JAGUNG & 73 & 3417.9 & 6.2926 & 2.8981 & 1.6279 & 1.1899 & 61.773 \\
GAMBLONG KERING & 0 & 0 & 0 & 0 & 0 & 0 & 0 \\
AMPAS TAHU KERING & 8 & 320.8 & 1.8112 & 0.4896 & 1.812 & 0.2096 & 0 \\
MINYAK SAWIT & 8 & 720 & 0 & 0 & 0 & 0 & 0 \\
& 100.00 & 4932.1 & 9.9606 & 3.9355 & 4.3947 & 1.8857 & 71.338 \\
\hline
\end{tabular}

Tabel 9. Kombinasi GE 5000 kkal dan protein kasar 12\%

\begin{tabular}{lrrrrrrr}
\hline \multicolumn{1}{c}{ Bahan Pakan } & \multicolumn{1}{c}{ \% } & GE & PK & LK & \multicolumn{1}{c}{ SK } & Ca & \multicolumn{1}{c}{ P } \\
\hline POLAR & 26 & 1119.1 & 4.3888 & 1.2948 & 2.2568 & 1.1492 & 22.61 \\
MPOK JAGUNG & 51 & 2387.8 & 4.3962 & 2.0247 & 1.1373 & 0.8313 & 43.156 \\
GAMBLONG KERING & 0 & 0 & 0 & 0 & 0 & 0 & 0 \\
AMPAS TAHU KERING & 13 & 521.3 & 2.9432 & 0.7956 & 2.9445 & 0.3406 & 0 \\
MINYAK SAWIT & 10 & 900 & 0 & 0 & 0 & 0 & 0 \\
& 100.00 & 4928.2 & 11.728 & 4.1151 & 0.3386 & 2.3211 & 65.766 \\
\hline
\end{tabular}


E. P. Santoso, A. Afrila dan E. Fitasari / Buana Sains Vol 17 No 1: 33 - 42

Tabel 10. Kombinasi GE $5000 \mathrm{kkal}$ dan protein kasar 14\%

\begin{tabular}{lrrrrrrr}
\hline \multicolumn{1}{c}{ Bahan Pakan } & \multicolumn{1}{c}{ \% } & GE & PK & LK & SK & Ca & \multicolumn{1}{c}{ P } \\
\hline POLAR & 13 & 559.53 & 2.1944 & 0.6474 & 1.1284 & 0.5746 & 11.305 \\
MPOK JAGUNG & 37.5 & 1755.8 & 3.2325 & 1.4888 & 0.8363 & 0.6113 & 31.733 \\
GAMBLONG KERING & 0 & 0 & 0 & 0 & 0 & 0 & 0 \\
AMPAS TAHU & 37.5 & 1503.8 & 8.49 & 2.295 & 8.4938 & 0.9825 & 0 \\
KERING & & & & & & & \\
MINYAK SAWIT & 12 & 1080 & 0 & 0 & 0 & 0 & 0 \\
& 100.00 & 4899 & 13.917 & 4.4312 & 10.458 & 2.1684 & 43.037 \\
\hline
\end{tabular}

Hasil penelitian dari pemeliharaan ulat jerman selama 35 hari menunjukkan bahwa ulat masih toleran terhadap pakan yang mengandung energi dan protein yang tinggi seperti halnya pada perlakuan G3P3.

Berdasarkan hasil penelitian bahwa GE dan PK pakan masing-masing memberikan pengaruh yang signifikan terhadap konsumsi BK konsentrat dan konsumsi BK sayur. Penggunaan limbah sayuran pasar ternyata mampu meningkatkan konsumsi pakan konsentrat yang mengandung GE 4000 $\mathrm{kkal} / \mathrm{kg}$ dan PK (G1). Hal ini disebabkan karena limbah sayur sendiri memiliki kandungan nutrisi yang tinggi terutama protein kasar dan GE yaitu PK 22,78\% dan gross energy 4624,94 kkal/kg. Hal ini menunjukkan bahwa limbah sayur dapat digunakan sebagai substitusi pakan ulat jerman untuk meminimalkan biaya pakan. Akan tetapi, penggunaan limbah sayur pada interaksi GE dan PK tidak memberikan hasil yang signifikan terhadap konsumsi konsentrat dan konsumsi BK total, kenenderungan konsumsi BK total yaitu BK sayur + konsentrat dihasilkan dari perlakuan G1P3 yaitu 1997,47 mg/ekor, yang diikuti oleh G1P2 1905,04 mg/ekor, dan G1P1 1889,87 mg/ekor.

Tabel 11. Hasil pengamatan terhadap konsumsi pakan

\begin{tabular}{|c|c|c|c|}
\hline & $\begin{array}{c}\text { Konsumsi BK } \\
\text { konsentrat }(\mathrm{mg} / \mathrm{e})\end{array}$ & $\begin{array}{l}\text { Konsumsi BK } \\
\text { sayur }(\mathrm{mg} / \mathrm{e})^{* *}\end{array}$ & $\begin{array}{c}\text { Konsumsi } \\
\text { BK total (mg/e) }\end{array}$ \\
\hline G1P1 & 1855,79 & $34,09 \mathrm{c}$ & 1889,87 \\
\hline G1P2 & 1872,47 & $32,58 c$ & 1905,04 \\
\hline G1P3 & 1976,9 & $20,56 b$ & 1997,47 \\
\hline G2P1 & 1642,94 & $32,58 \mathrm{c}$ & 1675,51 \\
\hline G2P2 & 1589,04 & $32,66 c$ & 1621,69 \\
\hline G2P3 & 1754,56 & $11,66 a$ & 1766,21 \\
\hline G3P1 & 1354,04 & $23,68 b$ & 1377,72 \\
\hline G3P2 & 1514,21 & $18,49 \mathrm{a}$ & 1532,71 \\
\hline G3P3 & 1552,55 & $14,77 \mathrm{a}$ & 1567,31 \\
\hline Uji F & $\begin{array}{c}\mathrm{P}>0,05 \\
\text { (tidak berbeda nyata) }\end{array}$ & $\mathrm{p}<0,01$ & $\begin{array}{c}\mathrm{p}>0,05 \\
\text { (tidak berbeda nyata) }\end{array}$ \\
\hline Nilai BNT & Tidak berbeda nyata & 7,16 & Tidak berbeda nyata \\
\hline
\end{tabular}

Ket: **a,b,c Notasi yang berbeda menunjukkan bahwa perlakuan memberikan pengaruh yang sangat nyata terhadap variabel pengamatan $(0<0.01)$

Penggunaan limbah sayur pada kombinasi GE dan PK yang lebih rendah yaitu pada perlakuan G2 dan G3 tidak menunjukkan konsumsi yang tinggi dan cenderung menurun hal ini diduga karena kandungan energi yang tinggi pada kedua 
perlakuan tersebut sehingga melebihi kebutuhan ulat jerman. Selain itu, diduga juga ulat jerman tidak terlalu toleran terhadap kandungan minyak yang semakin meningkat dengan meningkatnya kandungan gross energi. Hasil terendah dari perlakuan ini dapat dilihat pada G3P1 yang menunjukkan konsumsi BK total 1377,72 $\mathrm{mg}$ /ekor. Pada perlakuan ini konsumsi konsentrat semakin menurun (Tabel 11) sedangkan konsumsi limbah sayur pasar meningkat. Hasil ini menunjukkan bahwa ketika ulat tidak toleran terhadap pakan tertentu maka ulat akan mencari sumber pakan lain yaitu dari limbah sayur pasar yang kandungan lemaknya rendah. Penelitian Fitasari dan Santoso (2015) melaporkan ulat hongkong juga tidak toleran tetrhadap penggunaan energi tinggi hingga $5000 \mathrm{kkal} / \mathrm{kg}$, akibatnya bobot ulat hongkong cenderung turun dan bahkan mengalami mortalitas yang tinggi. Pada penelitian ulat jerman, ulat tidak mengalami kematian, hal ini disebabkan ulat memiliki postur tubuh yang lebih besar dibandingkan ulat hongkong yaitu bisa 7-10 kali lipat pada umur yang sama dan ulat jerman lebih toleran terhadap jenis pakan apapun. Konsumsi sayur yang cukup tinggi terjadi pada perlakuan G3P1 yaitu sebesar 23,68 mg/ekor, dan selanjutnya terjadi penuruan pada G3P2 dan G3P3 yaitu sebesar 18,49 dan 14,77 $\mathrm{mg} /$ ekor.

Penggunaan PK yang makin tinggi hingga 14\% pada semua perlakuan GE mampu meningkatkan konsumsi BK konsentrat (disajikan pada Tabel 12). Hal ini menunjukkan bahwa ulat jerman membutuhkan protein yang lebih tinggi untuk pencapaian bobot badannya. Sedangkan pada konsumsi limbah sayur, tidak dipengaruhi oleh kandungan PK konsentrat, namun lebih dipengaruhi oleh GE pakan, dimana semakin tinggi GE pakan pada pakan formulasi maka konsumsi sayur lebih cenderung menurun.

Tabel 12. Pengaruh Gross energy (GE) terhadap konsumsi pakan

\begin{tabular}{cccc}
\hline & $\begin{array}{c}\text { Konsumsi BK } \\
\text { konsentrat }(\mathrm{mg} / \mathrm{e})\end{array}$ & $\begin{array}{c}\text { Konsumsi BK } \\
\text { sayur }(\mathrm{mg} / \mathrm{e})\end{array}$ & $\begin{array}{c}\text { Konsumsi } \\
\text { BK total }(\mathrm{mg} / \mathrm{e})\end{array}$ \\
\hline GE 4000 & $5705,16 \mathrm{c}$ & $87,22 \mathrm{c}$ & $5792,38 \mathrm{c}$ \\
GE 4500 & $4986,53 \mathrm{~b}$ & $76,89 \mathrm{~b}$ & $5063,42 \mathrm{~b}$ \\
GE 5000 & $4420,80 \mathrm{a}$ & $56,94 \mathrm{a}$ & $4477,75 \mathrm{a}$ \\
\hline Uji F & $\mathrm{p}<0,01$ & $\mathrm{p}<0,01$ & $\mathrm{p}<0,01$ \\
\hline Nilai BNT & 125,34 & 5,69 & 125,01 \\
\hline
\end{tabular}

Ket: **a,b,c Notasi yang berbeda menunjukkan bahwa perlakuan memberikan pengaruh yang sangat nyata terhadap variabel pengamatan $(0<0.01)$

Penggunaan protein (disajikan tabel 3) menunjukkan bahwa penggunaan hingga $12 \%$ memberikan peningkatan pada konsumsi BK konsentrat, konsumsi BK sayur, dan konsumsi BK total, sementara penggunaan protein kasar 14\% menurunkan konsumsi BK sayur, konsentrat, dan BK total (Tabel 13). Hal ini diduga penurunan ini akibat kombinasi dengan GE yang semakin tinggi yaitu GE $5000 \mathrm{kkal} / \mathrm{kg}$ ulat tidak toleran. Hal ini karena pada penggunaan GE yang makin tinggi, penggunaan minyak juga semakin tinggi. Hal inilah yang menyebabkan ulat tidak tahan karena kulit dari ulat jerman sensitive terhadap kadar minyak yang tinggi 
E. P. Santoso, A. Afrila dan E. Fitasari / Buana Sains Vol 17 No 1: 33 - 42

Tabel 13. Pengaruh protein pakan (PK) terhadap konsumsi pakan

\begin{tabular}{cccc}
\hline & $\begin{array}{c}\text { Konsumsi BK } \\
\text { konsentrat }(\mathrm{mg} / \mathrm{e})^{*}\end{array}$ & $\begin{array}{c}\text { Konsumsi BK } \\
\text { sayur }(\mathrm{mg} / \mathrm{e})^{* *}\end{array}$ & $\begin{array}{c}\text { Konsumsi } \\
\text { BK total }(\mathrm{mg} / \mathrm{e})^{* *}\end{array}$ \\
\hline PK 10\% & $4852,77 \mathrm{a}$ & $90,34 \mathrm{c}$ & $4943,11 \mathrm{a}$ \\
PK 12\% & $4975,72 \mathrm{~b}$ & $83,73 \mathrm{~b}$ & $5059,45 \mathrm{~b}$ \\
PK 14\% & $5284,004 \mathrm{c}$ & $46,99 \mathrm{a}$ & $5330,99 \mathrm{c}$ \\
\hline Uji F & $\mathbf{p}<\mathbf{0 , 0 5}$ & $\mathbf{p}<\mathbf{0 , 0 1}$ & $\mathbf{p}<\mathbf{0 , 0 5}$ \\
\hline Nilai BNT & $\mathbf{9 0 , 9 7}$ & $\mathbf{5 , 6 9}$ & $\mathbf{9 0 , 7 3}$ \\
\hline
\end{tabular}

Ket: *a,b,c Notasi yang berbeda menunjukkan bahwa perlakuan memberikan pengaruh yang nyata terhadap variabel pengamatan $(0<0.05) ; * * a, b, c$ Notasi yang berbeda menunjukkan bahwa perlakuan memberikan pengaruh yang sangat nyata terhadap variabel pengamatan $(0<0.01)$

Selanjutnya, pengamatan dilakukan terhadap bobot badan, FCR, dan panjang badan yang disajikan pada Tabel 14, 15 dan 16. Gross energi memberikan pengaruh terhadap bobot panen $\mathrm{PBB}$, panjang badan $(\mathrm{p}<0.01)$ dan $F C R$ $(p<0.05)$ dengan hasil bahwa GE 4000 $\mathrm{kkal} / \mathrm{kg}$ menghasilkan nilai bobot panen dan PBB tertinggi. Hal ini senada dengan konsumsi BK pakan yang juga berpengaruh signifikan. Selanjutnya, protein kasar (PK) memberikan pengaruh terhadap PBB $(\mathrm{p}<0,01)$ dan FCR $(p<0,05)$. Pengaruh $P K$, nilai tertinggi dihasilkan pada perlakuan GE $5000 \mathrm{kkal} / \mathrm{kg}$ pada PBB, dan GE 4500 $\mathrm{kkal} / \mathrm{kg}$ pada FCR. FCR merupakan hasil dari pengubahan pakan untuk membentuk bobot badan. Semakin rendha nilai FCR maka akan semakin efisien pakan tersebut dicerna oleh tubuh. Akan tetapi dari hasil penelitian, nilai FCR yang makin rendah tidak selalu berkorelasi dengan PBB yang tinggi. Hal ini dapat dilihat pada hasil interaksi GE dan PK yang akan dijelaskan pada paragraf selanjutnya.

Hasil penelitian menunjukkan interaksi GE $4000 \mathrm{kkal} / \mathrm{kg}$ dan PK 14\% menghasilkan perbedaan yang sangat signifikan $(p<0,01)$ terhadap bobot panen ulat jerman umur 50 hari, dan tidak berbeda nyata terhadap PBB dan FCR. G1P3 menghasilkan bobot badan tertinggi yaitu $598 \mathrm{mg} /$ ekor yang diikuti oleh G1P2 yaitu 577,67 mg/e, G2P2 $542,33 \mathrm{mg} / \mathrm{e}, \mathrm{G} 2 \mathrm{P} 1530,67 \mathrm{mg} / \mathrm{e}$, dan G2P3 sebesar $525 \mathrm{mg} / \mathrm{e}$. Bobot dan terendah dihasilkan oleh G3P3 yaitu 439,33 mg/e. Bobot panen ulat jerman yang tinggi dari perlakuan G1P3 disebabkan konsumsi konsentrat yang tinggi yaitu 1976,6 mg, konsumsi konsentrat ini tidak diimbangi oleh konsumsi limbah sayuran pasar yang tinggi dibandingkan perlakuan lainnya yaitu $20,55 \mathrm{mg} / \mathrm{e}$. Hal ini diduga bahwa dengan kandungan nutrisi konsentrat yang ada, sudah mencukupi kebutuhan ulat jerman, kekurangan nutrisi akan tercukupi dari konsumsi limbah sayur, sehingga konsumsi BK total adalah 1997,47 dimana nilai ini tidak berbedanyata dibandingkan perlakuan lainnya. Berdasarkan perhitungan, G1P3 menghasilkan $\mathrm{PBB}$ yang paling tinggi dibandingkan perlakuan lainnya, namun tidak signifikan. Demikian pula pada FCR yang juga masih standar diman a nilai FCR G1P3 adalah 4,47. Dari hasil ini dapat disimpulkan, bahwa limbah sayuran pasar dapat berfungsi menggantikan pakan konsentrat yang selama ini digunakan sebagai pakan utama. Penggunaan limbah sayur di sini akan lebih menguntungkan, karena limbah sayur ini tersedia dalam jumlah melimpah dan peternak tidak perlu mengeluarkan biaya. 
Tingginya bobot badan pada perlakuan G1P3, tidak diimbangi oleh panjang badan ulat jerman . Ini menunjukkan bahwa bobot badan tidak selalu berkorelasi dengan panjang badan. Hal ini cukup wajar, karena pergerakan ulat jerman pada umur yang sudah dewasa sudah sangat cepat ketika bergerak di dalam nampan. Konsumen ataupun pasar menilai harga jual dari ulat jerman adalah berdasarkan dari bobot badan.

Tabel 14. Penampilan produksi dan FCR ulat jerman yang dipelihara selama 35 hari

\begin{tabular}{lcccc}
\hline $\begin{array}{c}\text { BB panen } \\
(\mathrm{mg} / \mathrm{e})^{* *}\end{array}$ & $\begin{array}{c}\text { PBB }(\mathrm{mg}) \\
35 \mathrm{hr} / \mathrm{ekor}\end{array}$ & FCR & $\begin{array}{c}\text { panjang } \\
\text { badan }(\mathrm{mm})^{*}\end{array}$ \\
\hline G1P1 & $481,33 \mathrm{a}$ & 307,83 & 6,21 & $45,46 \mathrm{a}$ \\
G1P2 & $577,67 \mathrm{~b}$ & 428,33 & 4,47 & $50,89 \mathrm{~b}$ \\
G1P3 & $598 \mathrm{c}$ & 447 & 4,47 & $49,29 \mathrm{a}$ \\
G2P1 & $530,67 \mathrm{~b}$ & 370,63 & 4,52 & $50,21 \mathrm{~b}$ \\
G2P2 & $542,33 \mathrm{~b}$ & 454,3 & 3,59 & $48,69 \mathrm{a}$ \\
G2P3 & 525b & 357,53 & 5,01 & $45,58 \mathrm{a}$ \\
G3P1 & 491a & 250,7 & 5,53 & $52,41 \mathrm{~b}$ \\
G3P2 & 459a & 309,87 & 5,16 & $52,01 \mathrm{~b}$ \\
G3P3 & $439,33 \mathrm{a}$ & 312,3 & 5,04 & $52,30 \mathrm{~b}$ \\
\hline Uji F & $\mathrm{p}<0,01$ & $\mathrm{p}>0.05$ & $\mathrm{p}>0.05$ & $\mathrm{p}<0.05$ \\
\hline BNT & 64,9 & Tidak berbeda nyata & Tidak berbeda nyata & 4,15 \\
\hline
\end{tabular}

Ket: ${ }^{* a, b}$, Notasi yang berbeda menunjukkan bahwa perlakuan memberikan pengaruh yang nyata terhadap variabel pengamatan $(0<0.05) ; * * a, b$ Notasi yang berbeda menunjukkan bahwa perlakuan memberikan pengaruh yang sangat nyata terhadap variabel pengamatan $(0<0.01)$

Tabel 15. Pengaruh gross energi (GE) terhadap penampilan produksi dan FCR

\begin{tabular}{lcccc}
\hline & $\begin{array}{c}\text { BB panen } \\
(\mathrm{mg} / \mathrm{e})^{* *}\end{array}$ & $\begin{array}{c}\text { PBB }(\mathrm{mg}) \\
35 \mathrm{hr} / \mathrm{ekor}\end{array}$ & FCR & $\begin{array}{c}\text { panjang } \\
\text { badan }(\mathrm{mm})^{*}\end{array}$ \\
\hline GE 4000 & $1657 \mathrm{c}$ & $1183,17 \mathrm{~b}$ & $15,16 \mathrm{~b}$ & $145,63 \mathrm{~b}$ \\
GE 4500 & $1598 \mathrm{~b}$ & $1182,47 \mathrm{~b}$ & $13,12 \mathrm{a}$ & $144,49 \mathrm{a}$ \\
GE 5000 & $1389,33 \mathrm{a}$ & $872,87 \mathrm{a}$ & $15,74 \mathrm{~b}$ & $156,73 \mathrm{c}$ \\
\hline Uji F & $\mathrm{p}<0,01$ & $\mathrm{p}<0,01$ & $\mathrm{p}<0.05$ & $\mathrm{p}<0,01$ \\
\hline BNT & 37,49 & 59,53 & 0,68 & 3,31 \\
\hline
\end{tabular}

Ket: ${ }^{* a, b, c}$ Notasi yang berbeda menunjukkan bahwa perlakuan memberikan pengaruh yang nyata terhadap variabel pengamatan $(0<0.05) ; * * a, b, c$ Notasi yang berbeda menunjukkan bahwa perlakuan memberikan pengaruh yang sangat nyata terhadap variabel pengamatan $(0<0.01)$

Tabel 16. Pengaruh protein pakan (PK) terhadap PBB dan FCR

\begin{tabular}{lcc}
\hline & PBB** & FCR* \\
\hline GE 4000 & $929,17 \mathrm{a}$ & $16,27 \mathrm{~b}$ \\
GE 4500 & $1192,5 \mathrm{~b}$ & $13,22 \mathrm{a}$ \\
GE 5000 & $1116,83 \mathrm{~b}$ & $14,53 \mathrm{~b}$ \\
\hline Uji F & $\mathrm{p}<0,01$ & $\mathrm{p}<0,05$ \\
\hline BNT & 59,53 & 0,68 \\
\hline
\end{tabular}

Ket: *a,b Notasi yang berbeda menunjukkan bahwa perlakuan memberikan pengaruh yang nyata terhadap variabel pengamatan $(0<0.05)$; **a,bNotasi yang berbeda menunjukkan bahwa perlakuan memberikan pengaruh yang sangat nyata terhadap variabel pengamatan $(0<0.01)$ 


\section{Kesimpulan dan Saran}

\section{Kesimpulan}

Berdasarkan hasil penelitian dapat disimpulkan bahwa ::

a. Aplikasi limbah sayuran pasar dalam media pakan ulat jerman mampu meningkatkan penggunaan pakan konsentrat yang mengandung gross energy dan protein kasar rendah

b. Perlakuan limbah sayuran pasar pada media pakan mengandung gross energi $4000 \mathrm{kkal} / \mathrm{kg}$ dan protein kasar 14\% menghasilkan nilai tertinggi terhadap konsumsi BK pakan, bobot panen, dan PBB

\section{Saran}

Limbah sayuran pasar dapat digunakan sebagai pakan substitusi dalam media pakan konsentrat yang mengandunga GE $4000 \mathrm{kkal} / \mathrm{kg}$ dan PK 14\%

\section{Daftar Pustaka}

Anonimousa, 2010. Budidaya Superworm, Prospek usaha yang sangat menggiurkan. www.http://komunikasimuthee.blogspot. com/2010/03/budidaya-superwormprospek-usaha-yang.html. Diakses pada tanggal 20 April 2015.
Anonimous b $2010 . \quad$ Superworm.

http://ulatjerman-

superworm.blogspot.com/. Diakses tanggal 21 April 2015)

Anonimus, 2015. Zophobas morio. www. bttp:/ / en.wikipedia.org/wiki/Zophobas morio . diakses tanggal 20 April 2015.

Anonimus, 2015. Siklus Hidup. http://ulatjermanblitar.blogspot.com/p/ blog-page.html. Diakses tanggal 21 April 2015.

Haffandi, L. 2012. Analisis Sampah Organik Dan Anorganik Di Tps Kota Malang. http://linda-

haffandi.blogspot.com/2013/03/analisissampah-organik-dan-anorganik.html. Diakses tanggal 4 Maret 2013.

Hartiningsih dan Fitasari, E. 2014. Aplikasi limbah sayuran pasar dan buah-buahan pada media pakan yang berbeda untuk meningkatkan bobot panen ulat jerman. BUANA SAINS.

Munandi, A. 2015. Ulat jerman lebih aman daripada ulat jerman. www. http://omkicau.com/2013/09/22/ulatjerman-lebih-aman-daripada-ulathongkong/. Diakses tanggal 20 April 2015

Userlele, 2011. Ulat jerman / superworm. www.

https://hanndyanifarm.wordpress.com/2 011/09/17/ulat-jerman-superworm/. Diakses tanggal 21 April 2015. 